\title{
Diet selection of Hereford, Angus $\times$ Hereford and Charolais $\times$ Hereford Cows and Calves
}

JOHN W. WALKER, R.M. HANSEN, AND LARRY R. RITTENHOUSE

\section{Abstract}

Botanical composition of cattle diets of Hereford, Angus $\times$ Hereford and Charolais $X$ Hereford cows and calves were compared to determine the effect of cattle age and/or breed on species selection. Multivariate analysis of variance showed small but significant differences between cow and calf diets and no differences among breeds. Similarity indices and Spearman's rank corr elation coefficient showed a high degree of over lap and significant correlation between ages and among breeds. Differences between cow and calves among breeds were minor and of little value in range management.

Knowledge of the factors affecting diet selection by livestock are important for proper forage allocation and utilization of range-

Authors are research associate, professor, and associate professor, Department of Range Science, Colorado State University, Fort Collins, Colorado 80523.

Manuscript received February 15, 1980.

This research was supported by Colorado State University Experiment Station and published as Scientific Series Paper No. 2583. lands. A review of the literature suggests that intraspecific variations in diet selectivity by domestic livestock may occur. Age has been shown to affect the nitrogen content of the diet of cattle and sheep. Holmes et al. (1969) found that (except when on abundant forage) calves had a higher concentration of fecal nitrogen than either cows or heifers, indicating that younger animals were more selective. Langlands (1969) using esophageally fistulated sheep found that younger animals tended to select diets higher in nitrogen than older animals; however, these results were not consistent across all experiments. Diet selection and grazing behavior of domestic animals may also be affected by breed. Herbel and Nelson (1966) using the bite count technique found that there was no apparent difference in the percentage of "coarse" plants grazed by Santa Gertrudis and Hereford cows. Although the Santa Gertrudis consumed more of the coarse grasses, the Herefords ate more Russian thistle (Salsola kali) and soaptree yucca (Yucca elata.) Time spent grazing by cattle has been shown to be affected by breed (Kropp et al. 1973, Stricklin et al. 1976). The digestibility and nitrogen content of diets selected by sheep was also affected by 
breed (Langlands 1968, 1969). The purpose of this study was to determine the effect of age and breed on botanical composition of diets selected by beef cattle.

\section{Study Area}

Research was conducted at the Eastern Colorado Research Center located $27 \mathrm{~km}$ north of Akron in the sandhills of northeastern Colorado. The elevation averages $1,300 \mathrm{~m}$ above sea level with the topography varying from nearly level to slightly rolling dunes. The vegetation is heterogeneous consisting of short, mid, and tall grasses as well as both cool-season and warm-season species. The major graminoids are blue grama (Bouteloua gracilis), prairie sandreed (Calamovilfa longifolia), needle-and-thread (Stipa comata), sand bluestem (Andropogon hallii), western wheatgrass (Agropyron smithii), and sand dropseed (Sporobolus cryptandrus). Sand sagebrush (Artemisia filifolia) is the principal shrub. Forbs common to the area include perennial ragweed ( $A m b r o s i a$ coronopifolia), cudweed sage (Artemisia ludoviciana), wild alfalfa (Psoralea tenuiflora) and bush morning glory (Ipomea leptophylla). The climate in this area is characterized by hot, often dry summers; mild, usually dry, autumns; cold winters; and moist, cool springs. The mean annual precipitation is $38 \mathrm{~cm}$. Most of this comes as rain during the frost-free period, about May 20 to October 20 (Sims et al. 1976).

\section{Procedures}

Diets were determined by microhistological analysis of fecal material from 18 cow-calf pairs. The experimental animals consisted of six Hereford, six Angus $\times$ Hereford and six Charolais $X$ Hereford cows and their calves. All calves were the progeny of the same Angus sire. The animals grazed a common 60-ha pasture. Fecal material was collected daily from each animal over a five-day period at 28-day intervals between May and August of 1976 for a total of four sample periods. Feces were composited within each sample period for all animals of the same breed and age. This resulted in a total of six composited fecal samples for each of the four sample periods.

Microscope slides for each fecal sample were prepared as described by Sparks and Malechek (1968). Five microscope slides were prepared per sample. Twenty fields per slide were systematically located and magnified $100 x$ for identification of plant fragments, for a total of 100 fields per sample. The percentage of the classified fragments appears to approximate the percentage relative dry weights of food categories in the diet (Hansen et al. 1973, Dearden et al. 1975).

The vector of the percentage of major plants species in the diet was analyzed by multivariate analysis of variance (Morrison 1967) to determine the effect of age and breed or their interaction. The effect of animal age and breed on the percentage of individual

Table 1. Average botanical composition (\%) of diets selected by cattle of various age and breed groups between May 26, 1976, and August 21, 1976, on sandhill range of northeastern Colorado.

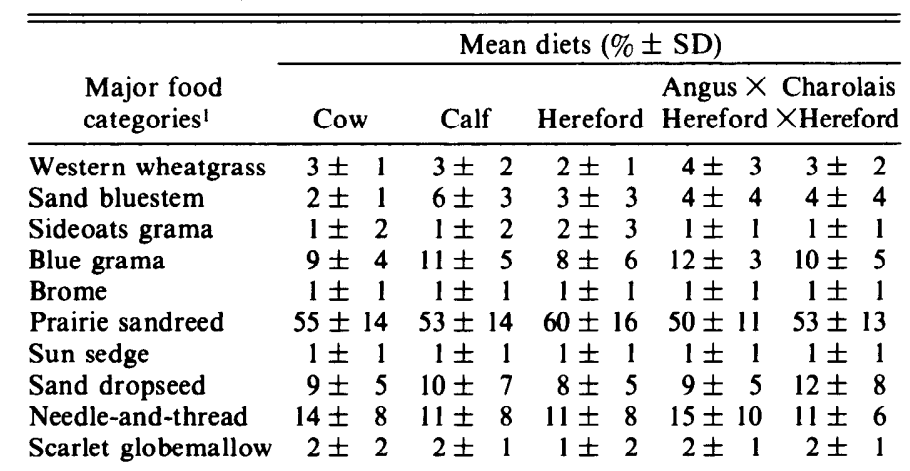

'Major feed categories include species which composed $2 \%$ or more of an individual diet.
Table 2. Mean diversity for foods in the diet of beef cattle on sandhill range in northeastern Colorado.

\begin{tabular}{lc}
\hline \hline Age or breed & Mean diversity index $( \pm$ SD) \\
\hline Cow & $1.38 \pm .27$ \\
Calf & $1.42 \pm .24$ \\
Hereford & $1.28 \pm .34$ \\
Angus $X$ Hereford & $1.48 \pm .18$ \\
Charolais $X$ Hereford & $1.43 \pm .19$
\end{tabular}

species in the diet and on the diversity of plants in the diet as calculated by Shannon's formula (Hurtubia 1973) was tested by analysis of variance (Snedecor and Cochran 1973). Dietary similarity indices (Gauch 1973) and Spearman's rank-order correlation coefficients (Snedecor and Cochran 1973) were used to compare food habits between ages and among breeds.

\section{Results}

The botanical components of the cattle diets were classified into 30 different plant taxa. Ten species composed $2 \%$ or more of at least one of the diets and were used for further analysis of the diets (Table 1). These species included western wheatgrass, sand bluestem, blue grama, sideoats grama (Bouteloua curtipendula), bromes (Bromus spp.), prairie sandreed, sun sedge (Carex heliophia), sand dropseed, needle-and-thread and scarlet globemallow (Sphaeralcea coccinea), and they comprised $97 \%$ or more of the diets. The diets for all groups of cattle were composed almost exclusively of grasses and were dominated by prairie sandreed which made up $50 \%$ or more of all diets.

Multivariate analysis of variance indicated that the age $\times$ breed interaction and the main effect of breed were not significant when the 10 major plant species were considered simultaneously. The effect of age (cows vs calves) was significant $(P<.05)$ and was due primarily to the greater abundance of sand bluestem in the diet of calves $(6 \%)$ as compared to cows $(2 \%)$. Analysis of variance of the individual species confirmed that the effect of age on percent sand bluestem in the diet was the only significant $(P<.05)$ difference in the diets. Sand bluestem is a very minor component of the vegetation on the study area and composed a relatively small proportion of the diet. Diet diversity was similar between cows and calves and among the three breed groups (Table 2). Shannon's diversity index is a measure of the variety and distribution of the species in the diet. This index increases as the number and uniformity of distribution of species in the diet increases. Smaller animals with greater energy requirements per unit of body size should be more selective, and diversity should decrease (Schoener 1971).

The rank-order correlation coefficients for plants eaten by cows and calves as well as for Herefords, Angus $X$ Hereford and Charolais $X$ Hereford cattle were significantly correlated (Table 3 ). The diets showed a high degree of similarity between the age groups and among the breed groups. High dietary overlaps and significant positive correlation coefficients between the cattle groups indicated that differences in the diets were small.

\section{Table 3. Average dietary overlap and Spearman's rank correlation co- efficients with the corresponding confidence values for foods of cattle of different ages or breeds on sandhill range of northeastern Colorado.}

\begin{tabular}{lccc}
\hline \hline & $\begin{array}{c}\text { Percentage } \\
\text { similarity }\end{array}$ & $\begin{array}{c}\text { Spearman's } \\
\text { RHO values }\end{array}$ & P values \\
\hline Relationship & 84 & .97 & .01 \\
\hline Cow vs calf & 84 & .92 & .01 \\
Hereford vs Angus $\times$ Hereford & & & \\
$\begin{array}{l}\text { Hereford vs Charolais } \times \\
\quad \text { Hereford }\end{array}$ & 85 & .91 & .01 \\
$\begin{array}{l}\text { Angus } \times \text { Hereford vs Charolais } \\
\quad \times \text { Hereford }\end{array}$ & 85 & .97 & .01 \\
\end{tabular}




\section{Discussion}

The results of this study suggest that differences in the nutrient content of the diets of livestock varying either in age or breed reported by other authors (Holmes et al. 1969, Langlands 1968, 1969) are probably due to differences in the portion of the plant that was selected rather than the botanical composition of the diet. Arnold (1975) found that the rate of forage consumption varied among breeds of free grazing sheep. These differences in rate of consumption may have been due to differing degrees of selectivity for the portion of a plant consumed. Observation of grazing cattle during this study indicated that cows may select different plant parts than calves. Lucich (1977) found diet overlap between doe and fawn mule deer similar to the one reported in this study for cows and calves.

Although multivariate analysis of variance showed that when the major plant species are considered simultaneously there is a significant difference in the diets selected by cows and calves, other measures of cattle diet selection indicated only small differences. Variations in the botanical composition of the diets because of age and breed effects are probably not large enough to be of value in understanding the dietary habits of cattle.

\section{Literature Cited}

Arnold, G.W. 1975. Herbage intake and grazing behavior in ewes of four breeds at different physiological states. Aust. J. Agr. Res. 26:1017-1024.

Dearden, B.L., R.E. Pegau, and R.M. Hansen. 1975. Precision of microhistological estimates of ruminant food habits. J. Wildl. Manage. 39:402407.

Gauch, H.G., Jr. 1973. The relationship between samples similarity and ecological distance. Ecology 55:618-266.
Hansen, R.M., D.G. Peden, and R.W. Rice. 1973. Discerned fragments in feces indicate diet overlap. J. Range Manage. 26:103-105.

Herbel, C.H., and A.B. Nelson. 1966. Species preference of Hereford and Santa Gertrudis cattle on a southern New Mexico range. J. Range Manage. 19:177-181.

Holmes, W., J.G.W. Jones, and R.M. Drake-Brockman. 1961. The feed intake of grazing cattle. Il. The influence of size of animal on feed intake. Animal. Proc. 3:351-360.

Hurtubia, J. 1973. Trophic diversity measurement in sympatric predator species. Ecology 54:885-890.

Kropp, J.R., J.W. Holloway, D.F. Stephens, Leon Knori, R.D. Morrison, and Robert Totusek. 1973. Range behavior of Hereford, Hereford $X$ Holstein and Holstein non-lactating heifers. J. Anim. Sci. 36:797-802.

Langlands, J.P. 1968. The feed intake of grazing sheep differing in age, breed, previous nutrition and liveweight. J. Agr. Sci., Camb. 71:167-172.

Langlands, J.P. 1969. Studies on the nutritive value of the diet selected by grazing sheep. IV. Variation in the diet selected by sheep differing in age, breed, sex, strain and previous history. Anim. Prod. 11:369-378.

Lucich, G.C. 1977. Plant taxa eaten by doe and fawn mule deer in north central Colorado. M.S. Thesis. Colorado State Univ., Fort Collins. 36 p.

Morrison, D.F. 1967. Multivariate Statistical Methods. McGraw-Hill Book Co., New York. 338 p.

Schoener, T.W. 1971. Theories of feeding strategies. Annu. Rev. Ecol. Syst. 11:369-404.

Sims, P.L., B.E. Dahl, and A.H. Denham. 1976. Vegetation and livestock response at three grazing intensities on sandhill rangeland in eastern Colorado. Colorado State Univ. Exp. Sta. Tech. Bull. 130. 48 p.

Snedecor, G.W., and W.C. Cochran. 1973. Statistical Methods. Iowa State Univ. Press, Ames. 593 p.

Sparks, D.R., and J.C. Malechek. 1968. Estimating percentage dry weights in diets using a microscope technique. J. Range Manage. 21:264-265.

Stricklin, W.R., L.L. Wilson, and H.B. Graves. 1976. Feeding behavior of Angus and Charolais-Angus cows during summer and winter. J. Anim. Sci. 43:721-732. 